Madu SN \& Peltzer $K$

\title{
THE RELATIONSHIP BETWEEN CHILD SEXUAL, PHYSICAL, PSYCHOLOGICAL, EMOTIONAL AND RITUALISTIC ABUSE AMONG HIGH SCHOOL STUDENTS IN THE NORTHERN PROVINCE, SOUTH AFRICA
}

Proff Madu and Peltzer are lecturers at the Department of Psychology, University of the North Sovenga

\begin{abstract}
This study is an investigation into the relationship between child sexual, physical, psychological, emotional and ritualistic abuse among high school students in the Northern Province (South Africa). Gender and urban-rural differences are also examined in relation to child sexual abuse. The method of secondary data analysis was used to analyse the same data used by Madu and Peltzer (1998, 2000) and Madu, Peltzer and Mashego (1998). Logistic Regression Analysis shows that among all the participants child sexual abuse correlates positively with psychological and emotional forms of child abuse. No gender correlated significantly with child sexual abuse. Chi-Square analysis for village-urban difference shows that child sexual abuse occurs more often in the urban areas than in the villages. The authors conclude that mental health workers and social workers should take note of the above relationship in planning preventive and therapeutic strategies for victims of child abuse in the area.
\end{abstract}

Key Words: Child abuse, high school students, South Africa.

\section{INTRODUCTION}

Child abuse is one of the major problems that demand urgent attention in South Africa. During the first six months of 1996 the Child Protection Units of the South African Police Services identified 19805 cases of crimes against children less than 18 years; of these, the number for child sexual abuses was 7968 (40\%) (rape: 7363, sodomy: 480 and incest: 125) (Piennar, 1996). Madu and Peltzer (1998) found the prevalence rates of child psychological, physical, emotional and ritualistic abuse among high school students in the Northern Province (South Africa) to be $80.7 \%, 19.8 \%, 26.3 \%$, and $8.0 \%$ respectively. They also found the prevalence of child sexual abuse among the same population to be 54.2\% (Madu \& Peltzer, 2000) and of childhood incestuous abuse to be $15.2 \%$. (Madu et al., 1998). These studies, however, failed to determine the relationship between sexual abuse and other forms of child abuse.

It is important to ascertain the relationship between child sexual abuse and other forms of child abuse, because in many societies people are not always willing to report child sexual abuse to the appropriate law enforcement agencies (see also Peltzer \& Phaswana, 2000). For example, research has shown that child sexual abuse has highly adverse effects on the victims and these effects can be long term or short term (Bergner, 1990; Collings, 1993, 1995, 1997; Finkelhor \& Browne, 1986). In spite of this, child sexual abuse is still often associated with shame, threat, fear or taboo by many families and societies. Thus many of the cases are not reported to the mental health workers, social workers or law enforcement agencies (Bagley \& Ramsey, 1985; Goodwin, 1988; Gutheil, 1991; Kraemer, 1988; Steele, 1991; Wolf, 1995). Given this attitude, the perpetrators go unreported and all the possible psychological, social and psychiatric short- 
term and long-term effects of such childhood abuse (as indicated by Briere, 1988; Frommuth \& Burkhart, 1987; Kluft, 1985; Leavitt, 1994; Sanders \& Giolas, 1991; Terr, 1992) are perpetuated.

The above situation poses a problem for mental health workers, social workers and law enforcement agencies. Is a victim of a reported case of child abuse most likely to have suffered from another form of child abuse as well, or is he or she likely to suffer from another form of child abuse in the future? These are questions that would interest psychologists, educators and social and other mental health workers who are confronted with the problems of child abuse in their planning of appropriate preventive and therapeutic strategies. Thus, there is the need to study the relationship between the different forms of child abuse.

To define child abuse (especially in an African context) is difficult and controversial since, as Lachman (1996) has explained, cultural attitudes towards child abuse vary a great deal; the distinction between (e.g., child physical) abuse and discipline is blurred, while the perception of child abuse as a "private" matter still prevails among many families (see also Kaplan, 1996; Kelley, 1989; King \& Yorker, 1996; Putman, 1991). Furthermore, in some of the literature the terms psychological and emotional abuse are used interchangeably (Adcock, White, \& Hallows, 1991; Finkelhor \& Karbin, 1990); emotional abuse is also often considered inherent in other types of abuse (Glaser \& Prior, 1997) and the boundary between physical and ritualistic abuse apparently overlaps.

The African Network for the Prevention and Protection Against Child Abuse and Neglect (ANPPCAN) defines child abuse as:

"The intentional, unintentional or well-intentioned acts that endanger the physical, health, emotional, moral and the educational welfare of the child. These acts are those morally unacceptable to the community that may endanger the wellbeing of the child, although the child may or may not perceive theses acts as abuse. Child neglect is the denial of the basic rights and needs of the child by parents, school, peers, governments and cultural community, occurring as acts of omission and or commission" (Ebigbo, 1989:404).

Practices viewed as acceptable by one culture can be viewed as abusive or neglectful in other cultures. However, while cultures vary in their definitions of child abuse and neglect, each group nevertheless has criteria for identifying behaviours that are outside the realm of acceptable child training. The significance of sociocultural components in the study of child maltreatment was emphasised in ecologically oriented models (Garbarino, 1992, 1995). These models highlight the interrelationships among the individual, familial, social and cultural components. Three primary theoretical models have been presented to explain child abuse: psychopathological, sociological and ecological (Roscoe, Callahan \& Peterson, 1985). The latter researchers found among adolescents that their results agree mostly with the psychopathological model, followed by the ecological model, and societal factors were seen (by the researchers) as relatively unimportant Zuravan (1989) found that strong predictors of child abuse and neglect are families with poverty indicators and that the pattern covariation between economic stress indicators and inadequate social support indicators is consistent with the ecological hypothesis. Gillham, Tanner, Cheyne, Freeman, Rooney and Lambie (1998) found among registered cases of abuse and neglect in Scotland that the male unemployment rate alone accounted for two thirds of the variance in total abuse and neglect rates. This literature (see also Garbarino \& Sherman, 1980; Reynolds, 1997; Scheper-Hughes, 1987) seems to suggest that local social factors play a role in the child abuse situation in different societal contexts. 
Mejuini (1991) addresses the issue of child abuse in Nigeria and the way that abuse seems to have escalated there. He argues that, although particular political and economic factors are implicated in the physical and sexual abuse of children in Africa, these factors find a fertile base in the ideological facets of African patriarchal traditions of family life, which facilitate the sexual abuse of women and girls. Levett (1994) states that one needs to be cautious in putting forward arguments about "cultural differences" in the southern African context, such as particular forms of patriarchal power.

Bayley and King (1990) define child sexual abuse as occurring when an adult or person significantly older or in a position of power interacts with a child in a sexual way for the gratification of the older person. The present study limits itself to any contact form of sexual abuse (i.e. actual or attempted intercourse, oral or manual genital contact, sexual kissing, hugging or touching) among the secondary school students which took place before the completion of their seventeenth year. The perpetrator must be an adult or a person at least five years older than the child or a person in a position of power.

Also for the purpose of this study, child psychological abuse is taken as any parental or adult care-taker's intentional and punitive verbal expressions that make a child feel psychologically bad. These expressions may take the form of yelling, insulting, criticising, generating guilt feelings, ridiculing or humiliating, embarrassing the child in front of others, making the child feel that he or she is a bad person (see Briere, 1992). Child physical abuse is understood here as purposeful non-verbal parental or adult care-taker's behaviour towards a child which is typically associated with physical pain and/or leading to fear of physical injury in the child (see also Briere \& Runtz, 1988; Ross, 1996). This behaviour may take the form of hitting, punching, cutting or pushing, which may result in bruises, scratches, broken bones or teeth, bleeding or hurting that requires medical attention (Briere, 1992). Lachman (1996) explains child emotional abuse to be an injury to a child's psychological self; its intent and effects are punitive and it is generally experienced as parental or adult care-taker's hostility or rejection, taking the form of verbal criticism, harassment or criticism of a child's failure to meet unrealistic expectations or standards for his or her performance. For this study child emotional abuse is understood as those parental or adult care-taker's behaviours which primarily involve physical actions or threat of physical harm, directly or indirectly, to a child (Briere, 1992). Child ritualistic abuse is referred to in this study as child physical torture, hurt or compulsion to do something sexual, which occurs during some sort of meeting, ritual, cult gathering or religious activity; or forcing a child to watch any of the above happen to someone else (Briere, 1992).

Many authors around the world have tried to establish the risk factors for child sexual abuse in a particular society (e.g. in Malaysia: Kassim \& Kassim, 1995; in Australia: Fleming, Mullenin, \& Bammer, 1997; in North America: Bergner, Delgado \& Graybill, 1994; Finkelhor, 1979, 1980, 1993, 1994; Finkelhor \& Baron, 1986; Finkelhor, Hotaling, Lewis \& Smith, 1990), but most of their findings do not agree. For instance, in North America, out of the eight risk factors found by Finkelhor 1979 (parental occupation, income, and education; religion; ethnicity; presence or absence of the father at home; presence of a step-parent; degree of violence at home; and the quality of parental marital home), only one factor (family income less than \$10,000) was confirmed by Bergner et al. (1994). In South Africa Collings (1991) found punitive or emotionally rejecting parents and separation from the natural father as significant factors. In comparing physically and sexually abused children, Collings (1993) also found out that the sexually abused children were older than the physically abused, and they were usually girls. The participants used in the two cases were different (male university 
students in the first study and reported victimised children in the second study). None of the above studies investigated the relationship between child sexual abuse and the other forms of child abuse.

Some authors have also conducted investigations into the problems of other forms of child maltreatment (e.g. Azar, Ferraro \& Breton, 1998; Briere \& Runtz, 1988; Cichetti \& Carlson, 1989). Haj-Yahia and Shor (1995) carried out an investigation into the social and cultural correlates for child psychological (physical and sexual) abuse, but the participants in the study tended to minimise all the factors as correlates. Some researchers have looked at child physical abuse from the point of view of parental factors and identified a history of abuse (Christmas, Wodarski \& Smokowski, 1996; Hlady \& Gunter, 1990), psychiatric illness (Christmas et al., 1996), low self-esteem (Christmas et al. 1996; Jason \& Andereck, 1983; McCurdy, 1995), social isolation (Christmas et al., 1996; McCurdy, 1995; Whipple \& Wilson, 1996), teenage parenthood (Christmas et al., 1996; Jason \& Andereck, 1983; Wekerle \& Wolfe, 1993), low economic status (Hlady \& Gunter, 1990; Jason \& Andereck, 1983; McCurdy, 1995), maternal hypothyroidism (Brethier \& Oriot, 1994), family violence (Hotaling, Finkelhor, Kirkpatrick, \& Straus, 1988; Milner, 1994; Hotaling, Whipple \& Richey, 1997), residential instability (Brent, Perper, Moritz \& Liotus, 1994), step-parenthood (Wekerle \& Wolfe, 1993), male perpetrators (Jason \& Andereck, 1983), black perpetrators (Jason \& Andereck, 1983) as correlates. Some looked at the correlates from the point of view of the social demographic variables of the physically abused child and identified the following as correlates: not growing up with both biological parents (Brent et al., 1994), presence of a step-parent during childhood (Brent et al., 1994), low family income (Hotaling et al., 1988; Whipple \& Richey, 1997), poor rural white family and poor urban black family (Jason \& Andereck, 1983). Knutson and Sullivan (1993) identified children's communication disorders (e.g. hearing, speech or language impairment) and enrolment in residential (school) programmes as correlates for child emotional abuse. Lawrence, Cozolino and Foy (1995) pointed out child sexual and physical abuse as correlates for child ritualistic abuse. The above literature review shows that only Lawrence et al. (1995) investigated the question of whether there is any other form of child abuse that correlates with child ritualistic abuse.

The Northern Province has a population of 5.4 million inhabitants: $97.1 \%$ are blacks, $0.1 \%$ are coloured, $0.1 \%$ are Indians/Asians, and $2.7 \%$ are whites; $45.7 \%$ of them are males and $54.3 \%$ are females; and many of the inhabitants live under poor economic and medical conditions (Health Systems Trust and Department of Health, 1997; Statistics South Africa, 2000). An investigation into the relationship between sexual abuse and other forms of abuse has not been conducted in the province. The authors will also look at the relationship from the point of view of gender. It is also of interest to investigate rural-urban sites in this respect, since differences may be expected.

\section{METHOD}

The authors used the method of secondary data analysis to analyse the same data used by Madu and Peltzer (1998, 2000) and Madu et al. (1998).

\section{PARTICIPANTS}

The participants for this study were all Standard 9 and 10 secondary (high) school students in three schools in the Northern Province. One of the schools is situated in a village (Graskop), one in a semi-urban area (Mahwelereng), while the other is in a city (Pietersburg). Standard 9 and 10 secondary school students were chosen because the authors believe that they are mature 
enough to have the courage to report on their psychological, physical, emotional and ritualistic abusive experiences and at the same time their ages are expected not to be too far above our operational maximum age for child sexual abuse (16 years). This means that they have the maximum opportunity to remember what happened before they were 17 years old. The total number of participants was 414; 193 of them (46.6\%) were males, $216(52.2 \%)$ females, while $5(1.2 \%)$ did not indicate their gender. Their mean age was 18.5 years $(\mathrm{SD}=2.18)$ and the age range was 14-30 years; $15(3.6 \%)$ did not indicate their age. Of the participants, $336(81.1 \%)$ were blacks, $51(12.3 \%)$ were whites, $10(2.4 \%)$ were coloured, $11(2.7 \%)$ were "other", who decided to describe their skin colour in other ways (e.g. "olive"), while 6 (1.4\%) did not indicate their skin colour. Two hundred and seven (50\%) live in villages, 107 (25.8\%) live in semiurban areas/towns, 94 (22.7\% live in a city, while $6(1.4 \%)$ did not indicate where they live.

\section{INSTRUMENT}

The instrument used for this study was an anonymous, retrospective and self-rating Child Maltreatment Questionnaire, an abbreviated and modified form of the child maltreatment interview schedule (Briere, 1992), which has the following components:

1. Questions on the demographic variables of the participants (gender, age, skin colour, and place of residence);

2(a) Questions on the (physical) contact forms of sexually abusive experiences of participants before the age of 17 years with an adult or person at least five years older or a person in a position of power, who was (were) the perpetrator(s). The patterns of contact sexual abuse considered were sexual kisses, touches and oral, anal or vaginal intercourse;

2(b) Questions on child psychological abuse asked the respondents to indicate (on a 7-point scale, ranging from "never" to "more than 20 times a year") how often a parent/stepparent/foster-parent/other adult in charge of him or her as a child (i.e. before the age of 17 years) ever made him or her feel psychologically bad by intentionally and in a punitive way, yelling, insulting, criticising him or her, trying to make him or her feel guilty, ridiculing or humiliating him or her, embarrassing him or her in from of others, or making him or her feel like he or she was a bad person. (For this study, an adult in charge of a child was explained to the participants to be any caretaker who is above 18 years old, irrespective of whether he or she is a relative or not.)

2(c) Questions on child physical abuse asked the respondents to indicate (by ticking "yes" or "no") whether a parent/step-parent/foster-parent/other adult in charge of him or her as a child (i.e. before the age of 17 years) ever did something on purpose to him or her (e.g. hitting, punching, cutting or pushing him or her down) that gave him or her bruises or scratches, broke bones or teeth, or made him or her bleed; and whether in any of the above cases the respondent was so badly hurt that he or she had to see a doctor or go to a hospital.

2(d) Questions on child emotional abuse asked the respondent to indicate (by ticking "yes" or "no") whether a parent/step-parent/foster-parent/other adult in charge of him or her as a child (i.e. before the age of 17 years) ever locked him or her in a room or closet or small space; ever tied him or her up or chained him or her to something; ever threatened to hurt or kill him or her; ever threatened to hurt or kill someone he or she cared about; ever threatened to leave him or her somewhere that frightened him or her or from where 
he or she would not be able to get back home; ever threatened to leave and never to come back.

2(e) Questions on child ritualistic abuse asked the respondents to indicate (by ticking "yes" or "no") whether there was ever a time during childhood (i.e. before the age of 17 years) that he or she was tortured, repeatedly hurt or forced to do something sexual during some sort of meeting, ritual, cult gathering or religious activity; and if not, whether he or she was ever forced to watch that happen to somebody else.

\section{Procedure}

The authors obtained permission from the Department of Education in the Province and from the principals of the schools to conduct the research in the schools. The school principals took the ethical responsibility of informing and obtaining the consent of the parents (where necessary) before the administration of the questionnaires. On the agreed dates with the schools and with the co-operation of the teachers, a research assistant distributed the questionnaire to all the school children in Standard 9 and 10 in the schools in their class rooms. The purpose of the research was first of all explained to the children; they were allowed to ask questions about the research before they were asked to complete the questionnaires to the best of their knowledge. It was also made clear to them beforehand that any of them who do not want to participate in the study should feel free to decline. A total number of four $(0.96 \%)$ students did not fill in their questionnaires. The questionnaires were collected on the same day that they were distributed to the participants.

In view of the fact that the questionnaire may have aroused some emotions, especially among the victimised subjects, the students were told to feel free to contact the researchers (through their telephone numbers and addresses provided to the students) in case there were questions or to enquire about counselling and/or psychotherapy. Alternatively, any clinical psychologist, psychotherapist or counsellor available could be consulted. Moreover, it was also agreed with the Department of Education that the results of the research should be made available to them for use in planning preventive health care services in the province.

The administration of the whole questionnaire was completed within three weeks in March 1998. Up until the time of writing up this research none of the participants has contacted the researchers for an abuse-related problem. A counsellor in one of the schools, however, reported that he is taking care of a case of physical abuse of one of the participants.

\section{Data analysis}

For sexual, physical, emotional and ritualistic abuse, the positive response of the participants were coded as 1 , while their negative responses were coded as 0 . For psychological abuse, the original version with a 7-point Lickert scale was recoded into (categorical) yes or no responses, where "never" $(0)$ remained zero $(0)$ and 1 to 6 were recoded as 1 . In our study there may be some isolated incidents of child psychological abuse which may not necessarily be regarded as indicative of an overall quality of parent-child interaction, but the authors believe that they (possibly) can have a highly detrimental effect on the child (depending on many factors such as the severity of the incidence and the lability of the personality of the child). Thus they were included as psychological abuse.

The data were analysed using the Statistical Package for Social Sciences (SPSS). 


\section{Results}

Table 1 shows Multiple Logistic Regression Analysis (Forward) for the relationship between child sexual abuse (on the one hand), and child physical, psychological, emotional and ritualistic forms of abuse, as well as gender (on the other hand) among all the participants.

TABLE 1

MULTIPLE LOGISTIC REGRESSION ANALYSIS (METHOD = ENTER) SHOWING THE RELATIONSHIP BETWEEN CHILD SEXUAL ABUSE (AS THE DEPENDENT

VARIABLE) AND CHILD PHYSICAL, PSYCHOLOGICAL, EMOTIONAL AND RITUALISTIC ABUSE, AS WELL AS GENDER (AS THE INDEPENDENT VARIABLES).

\begin{tabular}{|c|c|c|c|c|c|c|c|c|c|}
\hline \multirow{2}{*}{$\begin{array}{l}\text { Depen- } \\
\text { dent } \\
\text { Variables }\end{array}$} & \multicolumn{9}{|c|}{ Independent Variables in the Equation } \\
\hline & Forms of abuse & B & S. E. & Wald & Df & Sig & $\begin{array}{c}\mathrm{R} \\
\text { Squared }\end{array}$ & $\begin{array}{l}\text { Exp } \\
\text { (B) }\end{array}$ & $\begin{array}{l}\text { Overall } \\
\% \text { pre- } \\
\text { dicted }\end{array}$ \\
\hline \multirow[t]{6}{*}{$\begin{array}{l}\text { Sexual } \\
\text { abuse } \\
(\mathrm{n}=225, \\
54.2 \%)\end{array}$} & $\begin{array}{l}\text { Psychological } \\
\text { abuse } \\
(\mathrm{n}=334,80.7 \%)\end{array}$ & 0.059 & 0.016 & 14.225 & 1 & 0.000 & \multirow[t]{6}{*}{0.174} & 1.061 & \multirow[t]{6}{*}{70.2} \\
\hline & $\begin{array}{l}\text { Physical }(\mathrm{n}=80, \\
19.8 \%)\end{array}$ & 0.338 & 0.295 & 1.306 & 1 & 0.253 & & 1.402 & \\
\hline & $\begin{array}{l}\text { Emotional } \\
109,26.3 \%)\end{array}(\mathrm{n}=$ & 0.470 & 0.219 & 4.610 & 1 & 0.032 & & 1.601 & \\
\hline & $\begin{array}{l}\text { Ritualistic }(\mathrm{n}=33 \text {, } \\
8.0 \%)\end{array}$ & 0.798 & 0.252 & 0.603 & 1 & 0.437 & & 2.221 & \\
\hline & $\begin{array}{l}\text { Gender (Dummy } \\
\text { Variable): } 109 \\
(56.5 \%) \text { males and } \\
114(52.8 \%) \\
\text { females were } \\
\text { sexually abused }\end{array}$ & 0.196 & 0.252 & 0.603 & 1 & .437 & & 1.216 & \\
\hline & Constance & -0.473 & 0.216 & 4.775 & 1 & .029 & & 0.623 & \\
\hline
\end{tabular}

The table shows that, using sexual abuse as the dependent variable, the independent variables that correlate significantly with child sexual abuse are psychological abuse and emotional abuse. Therefore the presence of the two variables also suggests the presence of child sexual abuse. The R-Squared value shows that the two variables account for $17.4 \%$ of the variance in sexual abuse. The overall prediction is $70.2 \%$ correct.

For the purpose of the analysis the participants from urban and semi-urban areas were put together for the sake of comparison with the participants from the villages. Chi-Square (Pearson) for child sexual abuse with respect to village-urban differences shows a significant difference $\left(\right.$ Village $=105,53.6 \% ;$ Urban $\left.=117,66.1 \% ; X^{2}=6.061, \mathrm{df}=1, \mathrm{p}<0.05\right)$. 


\section{DISCUSSION}

The presence of child psychological and emotional abuse suggests the presence of child sexual abuse as well (and vice versa). Lawrence et al. (1995) rather found a significant correlation between child ritualistic abuse and sexual (and also physical) abuse. Marshall and Herman (1998) identified contextual conditions for child sexual abuse in South Africa as follows: (1) legacy of apartheid (e.g. labour system forced families apart, family and community support systems broke down); (2) institutionalised patriarchy (e.g. boys are socialised to have more power, male perpetrators are protected by state and families); and (3) the notion of children as property in association with a culture of domination and power that denies children recognition and rights (e.g. child abuse becomes normalised, laws and court procedures discriminate against children). Magwaza (1997:159) identifies the following external disinhibitors that could promote child sexual abuse:

- $\quad$ Lack of bonding with parent or parents, as in the case of the South African migrant labour system, which fragments family life and makes it difficult for fathers to bond with their children;

- Absence of the mother from the family and lack of supervision, common in Black families due to domestic work away from the family and poor childcare facilities;

- Unemployment, which is highest among Blacks; and

- Overcrowded household conditions (such as family members sleeping in one room) common among squatter and township families.

Emotional abuse and psychological abuse, however, overlap so much that many authors use them interchangeably (Adcock et al., 1991; Finkelhor \& Karbin, 1990). Thus, it is not surprising that the two variables go together in correlating with child sexual abuse.

No gender could significantly correlate with child sexual abuse. This is contrary to the view of Collings (1993), who holds that sexually abused children (in South Africa), when compared with those who are physically abused, were usually girls.

Village-urban comparison on the occurrence of child sexual abuse indicates that sexual abuse occurs significantly more often in the urban areas than in the villages. This suggests that the possible negative after-effects of urbanisation (e.g. loneliness, both parents working and are, therefore, often away from home, and alienation from traditional and cultural ties and norms) contribute significantly to the occurrence of child sexual abuse in the area of our study. Garbarino (1992, 1995), Garbarino and Sherman (1980), Gillham et al. (1998), Reynolds (1997), Roscoe et al. (1985), Scheper-Hughes (1987) and Zuravan (1989) agree that social and environmental factors play a role in child abuse situations in different societal contexts.

The above information is relevant to psychologists, educators, social workers and other mental health workers who are confronted with problems of child abuse. While planning preventive and therapeutic strategies for a victim of child sexual abuse, they should take other predicted forms of child abuse into consideration. This would help in preventing or minimising the shortterm and long-term health problems associated with childhood abuse (as indicated by Berger, 1990; Biere, 1988; Collings, 1993, 1995, 1997; Finkelhor \& Browne, 1986; Frommuth \& Burkart, 1987; Kluft, 1985; Leavitt, 1994; Sanders \& Giolas, 1991; Terr, 1992).

This study has some limitations. Only Standard 9 and 10 high school students were used for the study. This would limit the external validity of the findings in the province, since some children drop out of school before reaching Standard 9 or 10. Some researchers may also not want to include every single incidence of child psychological maltreatment as an abuse. The 
inclusion of such cases may account for the high prevalence of psychological abuse among our participants. Only $17.4 \%$ of the variance in child sexual abuse could be accounted for by child psychological and emotional abuse. Thus one should not rely solely on the two variables for the prediction of child sexual abuse.

\section{CONCLUSION}

We conclude that, on the basis of all the participants in our study, the identified relationship between child sexual abuse and child psychological and emotional abuse should be taken note of by mental health workers and social workers who are planning preventive and therapeutic strategies for victims of child sexual abuse in the province.

\section{ACKNOWLEDGEMENTS}

Thanks to the Department of Education of the Northern Province (South Africa), and the principals and students of the schools who participated in this study for their support and cooperation. We are also grateful to the University of the North, which provided a research grant for the study.

\section{REFERENCES}

ADCOCK, M.; WHITE, R. \& HALlOWS, A. (eds) 1991. Significant harm. Croydon: Significant Publications.

AZAR, S.T.; FERRARO, M.H. \& BRETON, S.J. 1998. Intrafamilial child maltreatment. In: OLLENDICK, T.H. (ed). Handbook of child psychopathology. New York: Plenum Press.

BAGLEY, C. \& RAMSEY, R. 1985. Sexual abuse in childhood: Psychosocial outcomes and implication for social work practice. Social Work and Human Sexuality, 4:33-47.

BAYLEY, C. \& KING, K. 1990. Child sexual abuse. London: Tavislock.

BERGNER, R.M.; DELGADO, L.K. \& GRAYBILL, D. 1994. Finkelhor's risk factor checklist: a cross-validation study. Child Abuse \& Neglect, 18:331-340.

BERGNER, R. 1990. Father-daughter incest: Degradation and recovery from degradation. In: PUTMAN, T. \& DAVIS, K. (eds) Advances in descriptive psychology (vol 5). Boulder, CO: Descriptive Psychology Press.

BRENT, D.A.; PERPER, J.A.; MORITZ, G. \& LIOTUS, L. 1994. Familial risk factors for adolescent suicide: A case-control study. Acta Psychiatrica Scandinavica, 89(1):52-58.

BRETHIER, M. \& ORIOT, D. 1994. Maternal graves' disease and child abuse: Response. Child Abuse and Neglect, 18(12):1087-1088.

BRIERE, J. 1988. The long-term clinical correlates of childhood sexual victimization. Annals of the New York Academy of Science, 528:327-334.

BRIERE, J.N. 1992. Child abuse trauma. London: Sage.

BRIERE, J. \& RUNTZ, M. 1988. Multivariate Correlates of childhood psychological and physical maltreatment among university women. Child Abuse and Neglect, 12:331-341.

CHRISTMAS, A.L.; WODARSKI, J.S. \& SMOKOWSKI, P.R. 1996. Risk factors for physical child abuse: A practice theoretical paradigm. Family Therapy, 23(3):233-248. 
CICHETTI, D. \& CARLSON, V. (eds)1989. Child maltreatment. Cambridge, MA: Cambridge University Press.

COLLINGS, S.J. 1991. Childhood sexual abuse in a sample of South African university males: Prevalence and risk factors. South African Journal of Psychology, 21:153-158.

COLLINGS, S.J. 1993. Physically and sexually abused children: A comparative analysis of 200 reported cases. Social Work, 29(4):301-306.

COLLINGS, S.J. 1995. The long-term effects of contact and non-contact forms of child sexual abuse in a sample of university men. Child Abuse \& Neglect, 19:1-6.

COLLINGS, S.J. 1997. Child sexual Abuse in a sample of South African women students: prevalence, characteristics, and long-term effects. South African Journal of Psychology, 27(1):37-42.

EBIGBO, P.O. 1989. Psychosocial aspects of child abuse and neglect in Africa. In: PELTZER, K. \& EBIGBO, P.O. (eds) Clinical Psychology in Africa. Frankfurt/M.:IKO Verlag, 401-424.

FINKELHOR, D. 1979. Sexually victimised children. New York: Free Press.

FINKELHOR, D. 1980. Risk factors in the sexual victimization of children. Child Abuse \& Neglect, 4:265-273.

FINKELHOR, D. 1993. Epidemiological factors in the clinical identification of child sexual abuse. Child Abuse \& Neglect, 17(1):67-70.

FINKELHOR, D. 1994 The international epidemiology of child sexual abuse. Child Abuse \& Neglect, 18:409-417.

FINKELHOR, D. \& BARON, L. 1986. High risk children. In: FINKELHOR, D.; ARAJI, S.; BROWNE, A.; PETERS, S \& WYATT, G. (eds) A sourcebook on child sexual abuse. Beverly Hills, CA: Sage, 60-88.

FINKELHOR, D. \& BROWNE, A. 1986. Initial and long-term effects: A conceptual framework. In: FINKELHOR, D.; ARAJI, S.; BARON, L.; BROWNE, A.; PETERS, S.D. \& WYATT, G.E. (eds) A source book on child sexual abuse. London: Sage.

FINKELHOR, D. \& KARBIN, J. 1990. The feelings of emotionally abused children. Social Work, 26:33-46.

FINKELHOR, D., HOTALING, G., LEWIS, I. \& SMITH, C 1990. Sexual abuse in a national survey of men and women: Prevalence, characteristics and risk factors. Child Abuse \& Neglect, 14:19-28.

FLEMING, J.; MULLEN, P. \& BAMMER, G. 1997. A Study of potential risk factors for sexual abuse in childhood. Child Abuse \& Neglect, 21(1):49-58.

FROMMUTH, M.E. \& BURKHART, B.R. 1987. Long-term psychological correlates of childhood sexual abuse in two samples of college men. Child Abuse \& Neglect, 13:533-542.

GARBARINO, J. 1992. The meaning of poverty in the world of children. American Behavioural Scientist, 35:220-237.

GARBARINO, J. 1995. Raising children in a socially toxic environment. San Francisco: Josey Bass. 
GARBARINO, J. \& SHERMAN, D. 1980. High-risk neighborhoods and high-risk families: the human ecology of child maltreatment. Child Development, 51:188-198.

GILLHAM, B.; TANNER, G.; CHEYNE B.; FREEMAN, I.; ROONEY, M. \& LAMBIE, A. 1998. Unemployment rates, single parent density, and indices of child poverty: their relationship to different categories of child abuse and neglect. Child Abuse \& Neglect, 22:7990 .

GLASER, D. \& PRIOR, V. 1997. Is the term child protection applicable to emotional abuse? Child Abuse Review, 6(5):315-329.

GOODWIN, J.M. 1988. Obstacles to policymaking about incest. In: WYATT, G.E. \& POWELL, G.E. (eds) Lasting effects of child sexual abuse. Newbury Park: Sage Publications.

GUTHEIL, TG 1991. Patients involved in sexual misconduct with therapist: Is a victim profile possible? Psychiatric Annals, 21(11):661-667.

HAJ-YAHIA, MM. \& SHOR, R 1995. Child maltreatment as perceived by Arab students of social science in the West Bank. Child Abuse and Neglect, 19(10):1209-1219.

HEALTH SYSTEMS TRUST AND THE DEPARTMENT OF HEALTH. 1997. Health care in the Northern Province. Durban: Kwik Kopy Printing.

HLADY, L.J. \& GUNTER, E.J. 1990. Alleged child abuse in custody access disputes. Child Abuse and Neglect, 14(4):591-593.

HOTALING, G.T.; FINKELHOR, D.; KIRKPATRICK, J.J. \& STRAUS, M.A. 1988. Family abuse and its consequences: New directions in research. Newbury Park: Sage.

JASON, J. \& ANDERECK, N.D. 1983. Fatal Child Abuse in Georgia: The epidemiology of severe physical child abuse. Child Abuse and Neglect, 7(1):1-9.

KAPLAN, S.J. 1996. Physical abuse of children and adolescents. In: KAPLAN, S.J. (eds) Family violence: A clinical and legal guide. Washington, DC. USA: American Psychiatric Press, 1-35.

KASSIM, K. \& KASSIM, M.S. 1995. Child sexual abuse: Psychosocial aspects of 101 cases seen in an urban Malaysian setting. Child Abuse \& Neglect, 19(7):793-799.

KELLEY, S. 1989. Stress response to children to sexual abuse and ritualistic abuse in day care centers. Journal of Interpersonal Violence, 4:502-513.

KING, G.F. \& JORKER, B. 1996. Case studies of children presenting with a history of ritualistic abuse. Journal of Child and Adolescent Psychiatric Nursing, 9(2):18-26.

KLUFT, R. 1985. Child multiple personality disorder: predictors, clinical findings, and treatment results. In: KLUFT, K. (ed), Childhood antecedents of multiple personality. Washington, DC: American Psychiatric Press, 125-140.

KNUTSON, J.F. \& SULLIVAN, P.M. 1993. Communicative disorders as a risk factor in abuse. Topics in Language Disorders, 13(4):1-14.

KRAEMER, S. 1988. Splitting and stupidity in child sexual abuse. Psychoanalytic Psychotherapy, 3(3):247-257. 
LACHMAN, P.L. 1996. Child protection in Africa: The road ahead. Child Abuse and Neglect, 20(7):534-547.

LAWRENCE, K.J.; COZOLINO, L. \& FOY, D.W. 1995. Psychological sequelae in adult females reporting childhood ritualistic abuse. Child Abuse and Neglect, 19(8):975-984.

LEAVITT, F. 1994. Clinical correlates of alleged satanic abuse and less controversial sexual molestation. Child Abuse and Neglect, 18:387-392.

LEVETT, A. 1994. Problems of cultural imperialism in the study of child sexual abuse. In: DAWES, A. \& DONALD, D. (eds). Childhood and adversity psychological perspectives from South African research. Cape Town: David Philip, 240-260.

MADU, S.N.; PELTZER, K. \& MASHEGO, T.-A.B. 1998. Childhood incestuous abuse among high school students in South Africa: Prevalence and risk factors. Journal of Psychology in Africa, 8(2):171-185.

MADU, S.N. \& PELTZER, K. 1998. The prevalence of child psychological, physical, emotional and ritualistic forms of abuse among high school students in the Northern Province (South Africa). Southern African Journal of Child and Adolescent Mental Health, 10(2):80-92.

MADU, S.N. \& PELTZER, K. 2000. Risk factors and child sexual abuse among secondary school students in the Northern Province (South Africa). Child Abuse and Neglect: The International Journal, 24(2):259-268.

MAGWAZA, A. 1997. Sexual abuse: a socio-cultural developmental perspective. In: REY, C.D.L.; DUNCAN, N.; SHEFER, \& VAN NIEKERK, A.V. (eds) Contemporary issues in human development: a South African focus. Halfway House, South Africa: International Thomson Publishing.

MAGWAZA, A.S. 1994. Perception of family relationships in sexually abused children. Social Work, 30(4):390-396.

MARSHALL, A. \& HERMAN, V. 1998. Child sexual abuse in South Africa. Cape Town: RAPCAN.

MCCURDY, K. 1995. Risk assessment in child abuse prevention programs. Social Work Research, 19(2):77-87.

MEJUINI, C.O. 1991. Educating adults against socioculturally induced abuse and neglect of children in Nigeria. Child Abuse and Neglect, 15:139-145.

MILNER, J.S. 1994. Assessing physical child risk: The Child Abuse Potential Inventory. Clinical Psychological Review, 14(6):547-583.

PELTZER, K. \& PHASWANA, N. 2000. Factors influencing child abuse and neglect reporting behaviour by social workers in the Northern Province, South Africa. Social Work/Maatskaplike Werk, 36(1):69-78.

PIENNAR, A. 1996. The Child Protection Unit (CPU) of the South African police service. Focus Forum (HSRC/RGN), 4(3):15-20.

PUTMAN, F. 1991. The satanic ritual abuse controversy. Child Abuse and Neglect, 15:175179. 
REYNOLDS, P. 1997. Childhood and traditional healing in Zimbabwe. Athens: Ohio University Press.

ROSCOE, B.; CALLAHAN, J.E. \& PETERSON, K.L. 1985. Who is responsible? Adolescents' acceptance of theoretical child abuse models. Adolescence, 20:189-197.

ROSS, S.M. 1996. Risk of physical abuse to children of spouse abusing parents. Child Abuse and Neglect, 20(7):589-598.

SANDERS, B. \& GIOLAS, M. 1991. Dissociation and childhood trauma in psychologically disturbed adolescents. American Journal of Psychiatry, 148:50-54.

SCHEPER-HUGHES, N. 1987. Child-survival: anthropological perspectives on the treatment and maltreatment children. Dordrecht: Riedel.

STATISTICS SOUTH AFRICA. 2000. Statistics in Brief. Pretoria: Central Statistics.

STEELE, B.F. 1991. The psychopathology of incest participants. In: KRAEMER, S. \& ATHTAR, S. (eds) The trauma of transgression: Psychopathology of incest victims. Northvale: Jason Aronson, Inc.

TERR, L. 1992. Childhood trauma: effects on psychological development. Eleventh Annual Joseph S. Skobbar Symposium held by Emory University School of Medicine at Grady Memorial Hospital, Atlanta, GA.

WEKERLE, C. \& WOLFE, D.A. 1993. Prevention of child physical abuse and neglect: Promising new directions. Clinical Psychology Review, 13(6):501-540.

WHIPPLE, E.E. \& RICHEY, C.A. 1997. Crossing the line from physical discipline to child abuse: how much is too much? Child Abuse and Neglect, 21(5):431-444.

WHIPPLE, E.E. \& WILSON, S.R. 1996. Evaluation of parent education and support programme for families at risk of physical child abuse. Families in Society, 77(4):227-239.

WOLF, A.P. 1995. Sexual attraction and childhood association: A Chinese brief for Edward Westermarck. Standford: Standford University Press.

ZURAVAN, S.J. 1989. The ecology of child abuse and neglect: review of the literature and presentation of data. Violence and Victims, 4:101-120. 